\title{
ANALISIS KETERLAMBATAN BERBICARA (SPECH DELAY) PADA ANAK STUDY KASUS ANAK USIA 10 TAHUN
}

\author{
Ratih Purnama Sari ${ }^{1)}$, Nuryani ${ }^{2)}$ \\ ${ }^{1}$ Universitas Islam Negeri Syarif Hidayatullah Jakarta \\ email: ratihpsarii@gmail.com \\ ${ }^{2}$ Universitas Islam Negeri Syarif Hidayatullah Jakarta \\ email: nuryani@uinjkt.ac.id
}

\begin{abstract}
Abstrak
Penelitian ini yaitu berawal dari keterlambatan bicara yang terjadi pada anak usia 10 tahun. Bahasa adalah sistem lambang bunyi yang arbiter yang dipergunakan oleh para anggota kelompok sosial untuk bekerja sama, berkomunikasi dan mengidentifikasi diri. Akan tetapi ketika berbicara tentang seorang yang mengalami keterlambatan berbicara, perkembangan tentang keterlambatan berbicara ini sangat sensitif terhadap perkembangan di bidang lain, yaitu psikologi, emosional, dan keadaan sekitarnya. Tujuan dari penelitian ini adalah untuk mengungkap beberapa faktor penyebab keterlambatan berbicara, kasus gangguan bahasa dan mengetahui penyebab keterlambatan berbicara yang dialami oleh anak usia 10 tahun. Metode yang digunakan dalam penelitian ini adalah metode penelitian deskriptif jenis studi kasus.
\end{abstract}

Kata kunci: keterlambatan berbicara, anak usia 10 tahun, jenis kasus, penyebab, penanganan.

\section{Abstract}

This research is started from the delay in speech that occurs in children aged 10 years. Language is a symbol system of sound that is the arbiter used by members of social groups to work together, communicate and identify themselves. However, when talking about a person who experiences delays in speaking, the development of this delay in speaking is very sensitive to developments in other fields, namely psychology, emotional, and the surrounding circumstances. The purpose of this study is to uncover several factors that cause speech delays, cases of language disorders and find out the causes of speech delays experienced by children aged 10 years. The method used in this research is descriptive research method type of case study.

Keywords: delays in talking, 10-year-old children, types, cases, causes, treatment.

\section{PENDAhUluan}

Berbahasa berarti berkomunikasi dengan menggunakan suatu bahasa. Bagaimana kemampuan bahasa dapat dikuasai manusia, berkaitan erat dan sejalan dengan perkembangan manusia. Kemampuan bahasa itu meliputi keterampilan berbicara, menulis, membaca dan mendengarkan. Keterampilan berbicara sebagai salah satu keterampilan berbahasa merupakan keterampilan produktif, sangat penting untuk dikuasai setiap manusia. Karena berbicara adalah proses komunikasi dengan lingkungan, menyampaikan pesan secara lisan kepada orang lain.

Dalam kajian psikolinguistik, yaitu cabang ilmu bahasa yang menyebutkan bahwa manusia yang normal fungsi otak dan alat bicaranya, tentu dapat berbahasa dengan baik. Namun, mereka yang memiliki kelainan fungsi otak dan alat bicaranya, tentu mempunyai kesulitan dalam berbahasa, baik yang produktif maupun reseptif. Jadi kemampuan bahasanya terganggu.

Bahasa berarti komunikasi dengan menggunakan suatu bahasa. Untuk dapat berbahasa diperlukan kemampuan mengeluarkan kata-kata. Ini berarti, daerah Broca sebagai gudang tempat menyimpan sandi ekspresi kata-kata di otak dan Wernicke sebagai Gudang tempat menyimpan sandi komprehensi kata-kata, harus berfungsi dengan baik. Jika terdapat kerusakan pada daerah tersebut dan sekitarnya menyebabkan terjadinya gangguan bahasa yang disebut afasia. Perkembangan bahasa dan bicara merupakan indikator penting perkembangan seorang anak. Perkembangan ini sangat sensitif terhadap perkembangan di bidang lain, yaitu bidang kognitif, sensor motoric, psikologi, emosional, dan keadaan sekitarnya. Sampai sekarang masyarakat kita masih kurang 
memperhatikan gangguan bicara tapi lebih memperhatikan cacat lain seperti gangguan penglihatan, pendengaran, tuna grahita dll. Oleh karena itu, hendaknya kita tinggalkan sikap menunggu dalam menghadapi gangguan bicara dan kita lakukan deteksi serta penanganan dini sehingga dapat kita cegah timbulnya gangguan yang lebih parah. Menurut penelitian problem ini terjadi atau dialami 5 sampai $10 \%$ anak-anak usia prasekolah dan lebih cenderung dialami oleh laki-laki daripada perempuan.

\section{METODE PENELITIAN}

Metode pengumpulan data yang digunakan dalam penelitian ini adalah dengan menggunakan observasi langsung. Data terdiri dari 2 yaitu, data primer dan data sekunder. Data primer adalah data yang diambil langsung dari responden melalui beberapa tahapan obeservasi sedangkan data sekunder adalah data pendukung yang diperoleh dari orangorang terdekat responden yang diteliti. Analisis Data Setelah dilakukan pengumpulan data secara manual selanjutnya data diolah dengan bantuan kom-puterisasi menggunakan uji statistic.

\section{HASIL DAN PEMBAHASAN}

Beberapa faktor penyebab keterlambatan berbicara pada anak sangatlah berbagai macam bentuknya dari gangguan yang disebabkan karna hal kecil sampai hal yang besar yang terjadi terhadap anak tersebut, yang menyebabkan beberapa faktor-faktor tertentu. Ada yang sembuh secara total atau ketika usia tertentu dan pula ada yang disebabkan karna sakit yang dideritanya. Beragam macam keterlambatan terjadi seperti sakit, gangguan mental, pendengaran, atau keterlambatan yang akan membaik dengan sendirinya.

Pendeteksian dini keterlambatan bicara sangat baik dilakukan karena kemungkinan pemulihan gangguan tersebut dapat ditanyai apabila masih dalam taraf gangguan bicara nonfungsional. Kegiatan deteksi dini tidak hanya melibatkan peran serta orang tua, keluarga, dokter anak yang merawat anak tersebut, tetapi juga melibatkan dokter kandungan yang merawat sejak kehamilan.

Keterlambatan bicara fungsional sering juga diistilahkan keterlambatan motorik (kematangan) dari proses saraf pusat yang dibutuhkan untuk memproduksi kemampuan bicara pada anak. Gangguan ini sering dialami oleh anak laki-laki dan sering terdapat riwayat keterlamabatan bicara pada keluarga. Biasanya hal ini merupakan keterlambatan bicara yang ringan. Pada umumnya kemampuan bicara akan tampak membaik setelah memasuki usia 2 tahun. Hal yang membuat keadaan seperti ini seringkali fungsi reseptif yang cukup baik begitupun juga dalam kemampuan suatu masalah visiomotorik terhadap anak yang mengalami keterlambatan seperti ini terjadi terhadap anak yang normal. Ciri yang ditunjukkan oleh anak terhadap fungsi ekspresif hanya gangguan ringan yang dialami anak tersebut. Anak juga tidak akan menunjukkan kelainan yang ia miliki, namun kita sebagai yang mengawasinya harus memperhatikan agar kelainan yang dialami oleh anak tersebut dapat kita ketahui contohnya pendengaran yang ia miliki, kecerdasan yang mampu ia kembangkan dan psikologis yang ia lakukan, gangguan bicara fungsional juga mengakibatkan gangguan berbahasa terhadap anak yang diderita. Ciri lain keterlambatan bicara nonfungsional biasanya termasuk keterlambatan yang berat. Keterlambatan dikatakan berat bila bayi tidak mau tersenyum sosial sampai 10 minggu atau tidak mengeluarkan suara sebagai jawaban pada usia 3 bulan. Tanda lainnya tidak ada perhatian sekitar sampai usia 8 bulan, tidak bicara sampai usia 15 bulan atau tidak mengucapkan 3-4 kata sampai usia 20 bulan.

Pada keterlambatan bicara nonfungsional harus dilakukan stimulasi sejak dini dan harus ditangani khusus oleh tenaga professional yang sesuai dengan sebabnya. Penanganan keterlambatan berbicara nonfungsional dilakukan melalui pendekatan medis yang sesuai dengan penyebabnya. Tenaga medis 
yang terlibat dalam menangani keterlabatan bicara nonfungsional yakni neurologi anak, gastroenterology anak, psikolog anak, psikiater anak serta praktisi atau klinisi yang berkaitan. Maka dari itu, orang tua beserta klinisi harus bisa melihat bedanya keterlambatan bicara fungsional serta bedanya nonfungsional agar bisa dideteksi sedini mungkin.

Keterlambatan bicara dan proses perkembangan bahasa pada anak, berbicara merupakan hal yang penting bagi manusia, dengan berbicara kita mengeluarkan suara yang mempunyai makna. Berbicara bukan sekedar mengeluarkan suara yang mengandung makna, tetapi adalah wujud dari apa yang terkandung dalam perasaan dan pikiran. Bicara dengan kata-kata yang tertata rapi, penuh makna, menunjukkan orang tersebut mempunyai pikiran yang benar. Keterlambatan bicara adalah gangguan pada kemampuan menghasilkan bicara sesuai dengan tingkat umur pada saat itu. Pada anak yang perkembangan bicaranya dikeluarkan sudah mampu dimengerti orang, walaupun belum begitu fokus.

Tahapan perkembangan berbicara pada anak yang normal adalah sebagai berikut.

1. Usia 12-15 bulan: kalimat belum jelas, dia mulai mengucapkan beberapa patah kata meskipun terdengar aneh karena pada usia ini ia baru mulai belajar untuk berbicara.

2. Usia 6-17 bulan: anak sudah dapat menguasai 7-20 kata termasuk pada kata yang baru didapatnya. Ini sudah mulai terdengar lebih bermakna.

3. Usia 18 bulan: anak sudah dapat merangkai 2 kata menjadi kalimat yang lebih sederhana, seperti "tidak mau”, "aku lapar".

4. Usia 21-30 bulan: anak sudah mencapai lebih dari 50 kata, dia sudah dapat menunjukkan kata saya untuk menyebut dirinya.

5. Usia 36 bulan: setealh berusia 3 tahun, setidaknya anak sudah menguasai 250 kata. Ia pun sudah mampu membentuk kalimat yang terdiri dari 3 kata. $\begin{array}{cccr}\text { Jika seorang anak } & \text { mengalami } \\ \text { keterlambatan bicara } & \text { maka } & \text { penyebab }\end{array}$ utamanya harus segera mendapat penanganan. Jika tidak gangguan yang lebih parah bisa mempengaruhi semua aspek perkembangan lainnya. Memasuki usia sekolah kosakata yang dikuasai si anak sudah banyak meskipun kadang lafal kata belum jelas. Biasanya lebih dari 1000 kosakata telah dikuasai. Anak yang mengalami keterlambatan dalam berbicara memiliki daya tangkap terhadap kosakata lebih lambat. Bisa saja pada umur 21 s.d 30 bulan ia baru bisa mengucapkan 2 kata.

Keterlambatan dan gangguan bicara ada banyak faktor menjadi penyebab. Penyebab keterlambatan bicara pada anak dapat berasal dari kelainan yang terjadi di jaringan otak ketika anak masih kecil dalam kandungan maupun penyakit yang didapat setelah lahir. Kelainan yang terjadi seperti retardasi mental akibat keterlambatan proses pematangan saraf dalam kandungan, gangguan bicara ekspretif, autism, gangguan perkembangan yang mengenai banyak system, keterlambatan perkembangan global.

Gangguan bicara pada anak bisa terjadi karena anak mengalami gangguan pada pendengarannya. Biasanya ia tidak akan bisa memberi respon terhadap bunyi-bunyi yang ada disekitar jika mengalami gangguan pendengarannya. Anak yang menderita tuli akibat infeksi di daerah telinga dapat pula menderita keterlambatan bicara. Hal ini berhubungan dengan bagaimana otak memahami, meniru, dan menggunakan Bahasa yang pernah didengarnya.

Keterlambatan akibat gangguan pada otot berbicara, ini dapat teridentifikasi dari cara anak melafalkan bicara yang tak jelas dan tak berujung sempurna otaknya sudah memerintahkan dan memberikan stimulus untuk menjawab dengan benar, tapi kata yang keluar dari mulut tidak jelas karena adanya gangguan neurologis atau persarafan.

Gangguan perkembangan bicara dan Bahasa juga muncul karena sebab-sebab lain: yaitu 1. Child-Aphasia (disebabkan karena 
traumatic, tumor, infeksi) 2. Landau-KleffnerSyndrom (gejala mirip pada pembagian bahasa reseptif) 3. Kemunduran perkembangan bahasa dan bicara dengan penyebab tak diketahui dengan atau tanpa epilepsy saat tidur dan gangguan nosology yang tak diketahui penyebabnya, sering juga terjadi pada Iautism Spectrum Disorder (ASD).

Gangguan pervasif yang disebabkan oleh anak, sering pula dialami anak yang mengalami gangguan perhatian. Salah satu keterbatasan atensi akan menyebabkan permasalahan pada pusat syaraf anak. Gangguan ini tidak berdiri sendiri tetapi dibarengi dengan ciri-ciri lain, misalnya sulit berkonsentrasi, dsb. Untuk memastikan adanya ganggua ini baiknya dibawa ke ahli.

Kurangnya interaksi dan komunikasi dengan orang tua dan lingkungan sekitar. Pemakaian bahasa dalam keluarga yang jumlahnya lebih dari satu, dapat membingungkan anak ketika akan bicara. Si anak cenderung hanya mau berbicara dengan orang tertentu saja. Bagi anak-anak yang berada di lingkungan seperti perumahan yang kurang memadai, kemiskinan, kurang gizi, kurang rangsangan orang tua tunggal maupun anak yang ditelantarkan, semua itu dapat menimbulkan gangguan berbicara pada anak. Banyak orang tua yang tidak menyadari bahwa cara mereka berkomunikasi dengan anak yang juga turut berpengaruh membuat anak tidak mempunyai banyak berbendaharaan kata-kata kurang dipacu untuk berpikir logis, membuat analisis maupun simpulan dari kalimat-kalimat yang diucapkan dengan sangat sederhana.

Agar anak tidak mengalami gangguan keterlambatan dan gangguan berbicara orang tua dapat memberikan stimulus-stimulus yang bermanfaat bagi perkembangan bicara anak baik di rumah ataupun di lingkungan sekitar. Biasakan anak untuk diajak berbicara dan berkomunikasi. Berikan waktu yang lama kepada anak untuk bermain dengan orang tua. Jangan biarkan anak menonton televisi terlalu lama karena pada saat anak menonton televisi anak cenderung menangkap informasi yang masuk kedalam stimulus yang ia cerna.

Biasakan anak untuk menedengarkan cerita atau dongeng yang bisa diberikan oleh orang tua. Ajarkan anak untuk mengucapkan kata atau ide dengan mengajarkan kata beserta tunjukkan benda atau objeknya. Dengan mengusahakan semakin tertariknya anak-anak untuk melakukan peniruan kata-kata. Anak akan mendapat respon yang sangat ekspresif, misalnya ketika anak mengungkapkan suatu ide kemudian orang tuanya memberikan respon seolah-olah terkejut, marah, atau menertawakannya maka anak akan mengulangi ucapan itu kembali. Anak begitu senang menerima respon timbal balik yang diberikan oleh orang tuanya. Anak merasa diperhatikan tanpa memperdulikan apakah perhatian tersebut berupa kemarahan atau ekspresi lainnya.

Dalam perkembangan kemampuan berbahasanya anak yang mengalami keterlambatan berbicara memerlukan waktu yang lebih lama untuk penangkapan maksud dari pembicara, bandingkan dengan anak yang normal.

Dapat disimpulkan bahwa anak yang mengalami keterlambatan dalam berbicara, proses perkembangan bahwasanya tidak sepenuhnya terganggu karena anak tersebut tidak gagap atau tidak seperti anak afasia, hanya ia memerlukan waktu yang agak lama untuk menangkap dan menyampaikan apa yang ada dalam pikirannya.

Namun diatas itu semua, hal yang paling utama adalah keterlambatan berbicara gagalnya seorang anak yang harusnya mampu, namun belum dicapai terhadap usianya karena disebabkan faktor yang dideritanya. Pertumbuhan yang tertinggal oleh tematemannya denga usia sebaya. Gangguan fisik yang mempengaruhi terhadap penelitian ini yaitu tumbuh kembang anak yang disebabkan karena Clubfoot atau CTEV: deformitas yang meliputi fleksi dari pergelangan kaki, inversi dari tungkai, adduksi dari kaki depan, dan rotasi media dari tibia. 
Cara yang harus dilakukan untuk mengatasi keterlambatan kemampuan bicara yang disebabkan pada anak adalah bacakan buku atau cerita bergambar sehingga anak dapat menunjuk atau memberi nama benda-benda yang ia kenal, gunakan bahasa yang sederhana ketika berbicara pada anak, mengoreksi ucapan yang salah dari anak. Misalnya ketika anak mengatakan "Atit" saat mengutarakan rasa sakit, orang tua segera membenarkannya dengan mengucapkan "Oh, sakit ya". Usahakan untuk selalu mengulang kata-kata yang diucapkan anak pada kita, berikan pujian pada anak ketika anak berbicara benar, jangan abaikan anak dan selalu berikan respon terhadap apa yang dikatakan anak, jangan memaksa anak untuk berbicara karena hal ini hanya akan membuat anak menjadi semakin tertekan, dan berkonsultasi kepada tenaga ahli seperti psikolog.

Dari pembahasan diatas dapat disimpulkan bahwa keterlambatan berbicara/ speech delay hasil yang didapatkan dari pemerikasaan psikologis dengan tujuan evaluasi intelegensi, psikogram yang didapatkan yaitu

\section{PSIKOGRAM}

\begin{tabular}{|c|c|c|c|c|c|c|c|c|c|c|c|c|c|c|c|c|c|c|c|c|}
\hline \multirow{3}{*}{ No } & \multirow{3}{*}{$\begin{array}{c}\text { aspek psikologis } \\
\text { Kemampuan Dasar }\end{array}$} & \multicolumn{19}{|c|}{ KLASIFIKASI } \\
\hline & & \multicolumn{4}{|c|}{ RENDAH } & \multicolumn{3}{|c|}{ KURANG } & \multicolumn{4}{|c|}{ CUKUP } & \multicolumn{4}{|c|}{ BAIK } & \multicolumn{4}{|c|}{ TINGGI } \\
\hline & & 1 & 2 & 3 & 4 & 5 & 6 & 7 & 8 & 9 & 10 & 11 & 12 & 13 & 14 & 15 & 16 & 17 & 18 & 19 \\
\hline 1 & Intelegensi Umum & & & & & $\mathrm{X}$ & & & & & & & & & & & & & & \\
\hline 2 & $\begin{array}{l}\text { Wawasan } \\
\text { Pengetahuan }\end{array}$ & & & & $\mathrm{X}$ & & & & & & & & & & & & & & & \\
\hline 3 & Daya Ingat & & & & $\mathrm{X}$ & & & & & & & & & & & & & & & \\
\hline 4 & Atensi Konsentrasi & & & & & $\mathrm{X}$ & & & & & & & & & & & & & & \\
\hline 5 & Pemahaman Verbal & & & & $\mathrm{X}$ & & & & & & & & & & & & & & & \\
\hline 6 & Penalaran Nonverbal & & & & & & & & & & & & & & & & & & & \\
\hline 7 & Penalaran Sosial & & & $\mathrm{x}$ & & & & & & & & & & & & & & & & \\
\hline 8 & Kemampuan Numerik & & & & $X$ & & & & & & & & & & & & & & & \\
\hline 9 & $\begin{array}{l}\text { Koordinasi Visual } \\
\text { Motorik }\end{array}$ & & & & & & & $x$ & & & & & & & & & & & & \\
\hline
\end{tabular}

Skor'IQ : 52 (Distabilitas Intelektual Tingkat Ringan, menurut Skala Wechsler)

Pada penelitian ini anak yang bernama Sulthon Maulana Irfani, di diagnosa keterlamabatn berbicara, dokter menganjurkan pada satu bulan menganjurkan sampai 8 kali pada jadwal terapi tanggal 09 mei 2019. Kondisi kesehatan berupa aspek fisik yang dialami oleh pasien bernama Sulthon Maulana Irfani pada pendengaran, penglihatan dan gigi cukup baik.

Kapasitas kecerdasan anak ini berada pada tara distabilitas intelektual tingkat ringan dengan skor IQ sebesar 52 (rentan skor 52-65). Hasil tersebut menunjukkan bahwa kapasitas kecerdasan anak ini tergolong kurang ia cenderung kesulitan dalam menangkap dan memproses informasi, terkendala untuk berkomunikasi dua arah secara memadai maupun bersosialisasi dengan teman-teman sebaya, serta kurang mampu berprilaku efektif sesuai tuntutan lingkungan.
Dalam aspek verbal, nampak sekali kesulitan anak ini untuk memahami instruksi. Ia tak kunjung memahami instruksi walau sudah disampaikan dalam kalimat yang sederhana. Ia harus diberikan contoh cara pengerjaan secara konkrit beberapa kali. Selain itu, ia juga masih membutuhkan pendamping ketika disekolah untuk mengerjakan tiap item tesnya. Hal ini menunjukkan kurangnya daya tangkap pada anak ini. Kemampuan komunikasi dua arahnya tidak memandai. Ia tidak mampu merespon pertanyaan secara tepat. Bila ditanya, ia hanya mangap, tertawa, atau mengulangi ucapan lawan bicara. Kosakatanya cendrung sedikit dan ucapannya tidak jelas. Ia juga belum mampu mengutarakan pikirannya dalam bentuk kalimat.

Wawasan pengetahuan anak ini sangat terbatas. Ia belum mengetahui fungsi benda dan nama hari dalam seminggu. Kemampuan 
logika penalaran anak ini kurang berkembang membuat ia tidak mampu memahami hubungan sebab-akibat maupun makna situasi, sehingga gagal menemukan solusi pemecahan masalah ia pun belum memahami konsep abstrak, seperti lawan kata dan analogi. Pada tugas berhitung, kemampuan anak ini terbatas pada menghitung objek yang konkret, tapi belum bisa menyelesaikan operasi hitung. Tidak hanya daya tangkap, anak ini pun menemui kendala dalam daya ingat. Daya ingatnya yang singkat, yaitu maksimal empat hal dalam sekali waktu, membuatnya perlu lebih banyak mengulang materi.

Pada aspek non-verbal, kemampuan anak ini pun tergolong kurang. Ia cukup mampu menyelesaikan tugas motorik praktis, seperti meniru gambar, tapi tidak bisa menyelesaikan tugas motorik yang kompleks. Ia masih belum dapat mneyusun balok berdasarkan warna (pengetahuan akan warna masih inkonsisten), bingung mengidentifikasi tiap bagian pada tugas bongkar pasang (harus sangat diarahkan), dan sering kali terbalik dalam mengenali urutan gambar. Ia juga tidak bisa mengidentifikasi bagian-bagian yang hilang pada suatu objek. Dapat disimpulkan, kemampuan anak ini terbatas pada meniru, namum belum bisa memahami. Anak ini membutuhkan waktu yang lambat untuk merespons instruksi dan kecepatan kerjanya juga lamban. Oleh karena itu, ia gagal menyelesaikan tugas-tugas yang menguji ketangkasan. Ia juga kurang telaten untuk menangani tugas-tugas yang menuntut ketelitian.

Anak ini cenderung kurang kooperatif selama proses pemeriksaan. Ia sulit fokus dan sangat mudah kehilangan konsentrasi. Sepanjang tes, soalanya senantiasa ditempelkan ke atas meja dan asyik mengemuti lengannya. Ia juga sukar duduk tenang, melainkan terus-menerus berdiri dan melongok ke luar jendela. Ia perlu diingatkan berulangkali untuk melihat ke depan dan mengerjakan tugas di hadapannya. Ia pun akan kembali tidak konsentrasi tak lama kemudian. Tangannya pun tidak bisa diam. Ia kerapkali mengambil berbagai hal yang menarik perhatiannya atau memukul-mukul meja. Daya tahan kerjanya rendah. Ia mudah merasa bosan dan saat bosan, ia akan merajuk meminta tes dihentikan. Ketika diarahkan, ia malah mengamuk dengan berteriak-teriak dan menendangi meja. Sikapnya yang belum mampu diajak bekerjasama ini mengakibatkan proses pemeriksaan menjadi lebih lama dan lebih sulit.

Kapasitas kecenderungan anak ini yang berada pada taraf disabilitas intelektual tingkat ringan tergolong kurang memadai untuk menjalani kegiatan belajar-mengajar di sekolah umum. Sebaiknya ia melanjutkan Pendidikan di Sekolah Luar Biasa (SLB) - C untuk anakanak tuna grahita. Anak ini dapat berperan lebih optimal bila diarahkan untuk berlatih keterampilan-keterampilan praktis dibandingkan penguasaan kemampuan akademik yang kompleks. Dalam proses belajar, penggunaan alat peraga, praktek, dan contoh yang aplikatif dapat dimanfaatkan untuk membantunya belajar. Sajikan informasi secara bertahap dan berikan informasi baru setelah informasi sebelumnya telah dipahami. Perbanyak mengulangi materi dan dapat menggunakan alat bantu mengingat. Buat jadwal harian dan aturan-aturan, terutama aturan belajar, serta terapkan system konsekuensi yang tegas. Kurangi waktu untuk menonton televisi dan bermain gawai, lalu isi waktu luang dengan kegiatan yang lebih bermanfaat, seperti membaca buku, latihan motoric halus, dan mengerjakan tugas-tugas rumah tangga. Anak ini juga membutuhkan pendamping intensif selama proses belajar untuk memastikan memahami informasi dan menyelesaikan tugas-tugasnya sesuai dengan standar capaian.

\section{KESIMPULAN}

Dari pembahasan diatas dapat disimpulkan bahwa gangguan keterlambatan berbicara atau speech delay ini terjadi pada anak usia 10 tahun, salah satu faktornya yaitu penyakit STEV yang pernah dialaminya ketika berusia 13 bulan, bukan penyebab karna faktor genetik namun gejala penyakit yang pernah diderita hingga anak ini yang seharusnya normal seperti anak-anak lainnya namun harus kembali lagi seperti anak bayi usia 2 bulan, ketika usia 13 bulan ia dirawat karna penyakit kejang sempat mengalami koma 4 hari tidak sadar. Sehingga menyebabkan anak ini mengalami keterlambatan berbicara prasekolah di usia 10 tahun ini. Sehingga hal pertama yang harus dilakukan untuk menangani gangguan keterlambatan berbicara pada anak ini yaitu memberikan nutrisi yang cukup agar 
si anak ini tumbuh optimal secara fisik maupun psikis. Jadi, dalam hal seperti ini orang tua harus lebih mengarahkan anak tersebut agar dapat mengembangkan potensi keadaan saat ini yang dialami oleh anak itu, orang tua juga harus sering rutin untuk mengantar anak ke psikologis untuk diterapi.

\section{DAFTAR PUSTAKA}

Chaer. 2003. Linguistik Umum. Jakarta: PT: RINEKA CIPTA.

Nur Indah, Rohmani. 2017. Gangguan Berbahasa kajian pengantar. UIN: Maliki Press.

Subyantoro. 2013. Gangguan Berbahasa Mengenali Untuk Mengantisipasi Sejak Dini. Yogyakarta: Ombak Dua. 